\title{
Effects of Health Education Based Intervention on Community's Perception, Healthy House, and Social Capital of Dengue in Endemic Area of Sleman Regency Indonesia
}

\author{
Tri Wahyuni Sukesi ${ }^{1,2 \star}$ D , Tri B. T. Satoto ${ }^{3}$, Elsa H. Murhandarwati ${ }^{3}$, Retna Siwi Padmawati ${ }^{4}$ \\ ${ }^{1}$ Doctoral Program in Medicine and Health, Faculty of Medicine, Public Health and Nursing, Universitas Gadjah Mada, \\ Yogyakarta, Indonesia; ${ }^{2}$ Department of Environmental Health, Faculty of Public Health, Universitas Ahmad Dahlan, Yogyakarta, \\ Indonesia; ${ }^{3}$ Center for Tropical Medicine, Faculty of Medicine, Public Health and Nursing, Universitas Gadjah Mada, Yogyakarta, \\ Indonesia; ${ }^{4}$ Department of Health Behavior, Environment, and Social Medicine, Faculty of Medicine, Public Health and Nursing, \\ Universitas Gadjah Mada, Yogyakarta, Indonesia
}

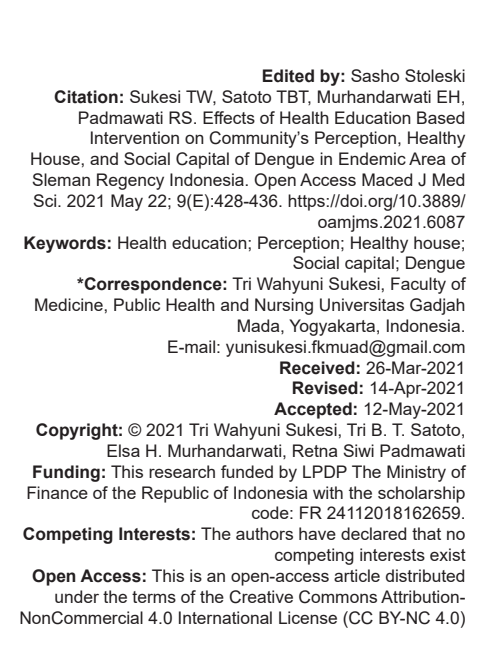

Abstract

BACKGROUND: Low community participation in the dengue hemorrhagic fever (DHF) control efforts is one of the influencing factors in the failures of some of these efforts. The community's lack of responsibility concerning the DHF issues might be caused by their low perceptions and understanding of DHF itself.

AIM: This study aimed to assess the effect of health education about DHF on changes in the community's perceptions, social capital, and healthy house conditions.

METHODS: The research method was participatory action research. The study involved 267 households in Patukan Hamlet Sleman Yogyakarta Indonesia. The intervention was health education about DHF which was presented from November 2018 to February 2019. Preliminary assessments were taken in November 2018 and evaluations were taken in August 2019. The data were analyzed with the Wilcoxon test.

RESULTS: The results show that in the $6^{\text {th }}$ months after the intervention, there was an increase in the average score of all variables. The differences between pre- and post-intervention were statistically significant: Perceptions of dengue fever $(p=0.000)$; perceptions about DHF control $(p=0.000)$; the social condition for the component of concern, trust, and readiness to learn new ideas with $p<0.05$; and all component of healthy house conditions with $\mathrm{p}<0.05$.

CONCLUSION: Health education could contribute to changes in perceptions, social capital, and a healthy house condition. It is very important to increase the awareness and participation of the community in controlling DHF.

\section{Introduction}

Dengue hemorrhagic fever (DHF) is one of the endemic diseases in tropical areas, including Indonesia. The high density of rainfall and low sunlight is good conditions for Aedes aegypti to multiply [1]. In addition to climate factors, a dirty environment can also influence the $A$. aegyptimosquitos' reproduction [2]. The non-hygienic environment is the result of the people's unhealthy behaviors, which are highly influenced by their perceptions [3]. In Indonesia, Yogyakarta Province was reported to have a high number of annual DHF case occurrences [4] (Figure 1) and Patukan has the highest incident rate $(I R=150.8)$ [5]. This number remains high despite several DHF controlling efforts, such as fogging, applying larvicide, and sending Jumantik cadres to perform monthly larvae inspection at the house of every community member [6]. The annual DHF case occurrences in Yogyakarta are always high [7]. This pattern reveals that the efforts in controlling DHF cases have not reached a satisfying level yet [8]. The low community participation in the DHF control efforts is one of the influencing factors in the failures of some of these efforts [9]. The community's lack of responsibility concerning the DHF issues might be caused by their low perceptions and understanding of DHF itself [10].

Putnam in 2001 argued that social capital shows the characteristics of social structures, such as networks, norms, and social beliefs for mutual benefits. The existence of good social capital can facilitate the health promotion process [11]. According to a health promotion program developed by Berkman, the aim to make a community empowered is an effort to strengthen social capital [12]. Social capital in the form of customs, culture, and norms adopted by the community has a role in shaping human behavior which, in turn, has an influence on the environment [13], [14]. Low social capital and perceptions about DHF contribute 


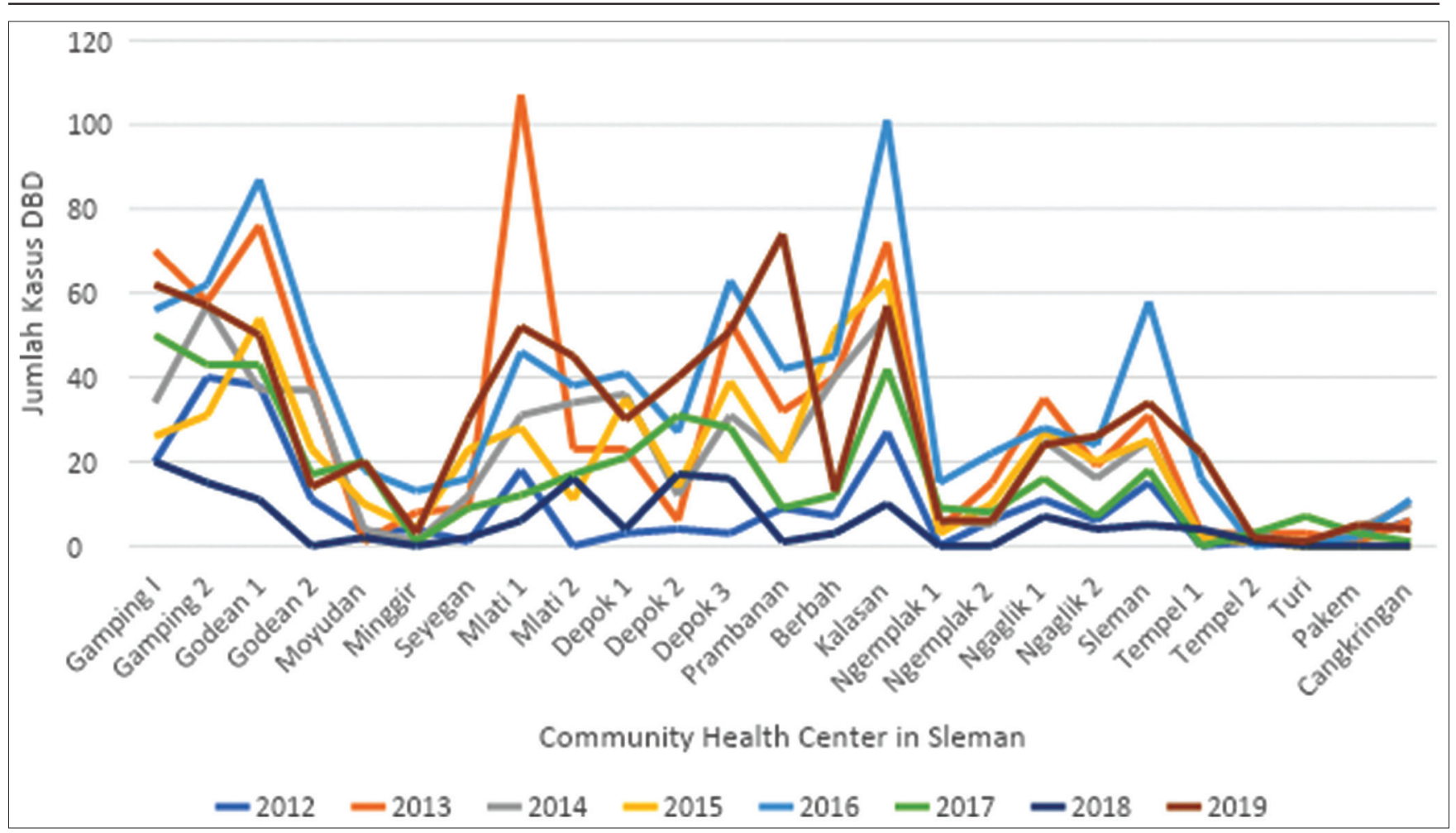

Figure 1: Data on dengue hemorrhagic fever cases in Sleman Regency, Yogyakarta Special Region Province 2012-2019 [4]

to creating a neighborhood including the condition of the house that supports DHF transmission [15]. The socialization of DHF control has been conducted to the lowest level of the community, but the perception and social conditions of the community tend to underestimate DHF which prevents all DHF control programs from running well [15], [16], [17], [18]. It needs proper attention to change perceptions, social capital, and the house environment to be better through community-based health education [3], [19], [20], [21]. Research showed that the community's perceptions can be influenced by health education [22], [23]. The fact that DHF control has always been neglected by most communities makes every community-based DHF control effort prone to failure [3]. In general, many members of a community perceive DHF as a common and less threatening disease. To change this perception, health education with accurate DHF facts is necessary [24]. This study was aimed to assess the effect of providing health education about DHF on changes in the community's perceptions, social capital, and healthy house conditions.

\section{Materials and Methods}

\section{Study design and participants}

Participatory action research was used in this study (Figure 2). The research subjects were the households in Patukan hamlet Sleman Yogyakarta. The number of research subjects was 267 households by applying the total sampling technique. Patukan has the highest incident rate of DHF (IR = 150.8) [5].

Phase 1: Initial assessment before the intervention was carried out (November 2018)

Phase 2: Intervention (December 2018February 2019)

Phase 3: Final assessment after 6 months of intervention (August 2019).

\section{Intervention}

Based on the initial data, the intervention applied in this research was health education about DHF. In delivering the DHF education, the researcher was assisted by ten fresh graduates from the Faculty of Public Health who had undergone a 1-week training to synchronize their perceptions on DHF and improve their understanding of DHF. The pre-post-test showed that the training of the trainer could improve the trainers' understanding of DHF ( $p$-value $0.000<0.005$ ). Interventions were delivered naturally by collaborating with the routine activities carried out by the target community. The researchers explained the material and the participants were invited to discuss dengue issues. In this forum, the participants received accurate education about dengue. The community health center (Puskesmas) as the closest health service facility to the community and village government was involved in the implementation of this health education intervention. Health education about dengue was provided regularly 


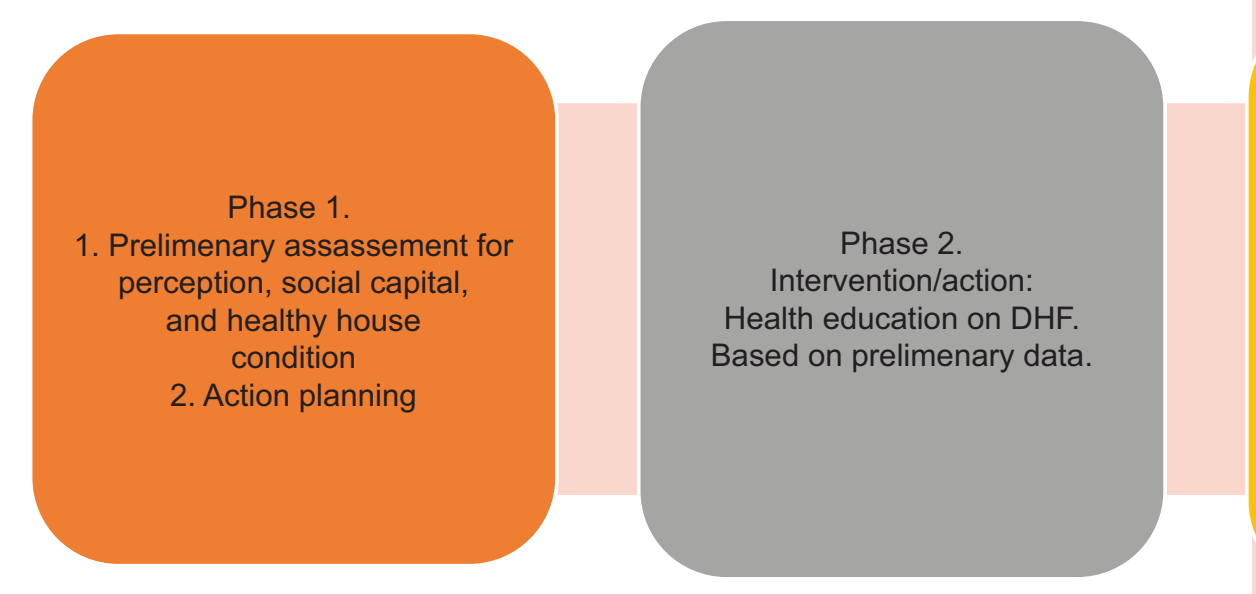

Phase 3.

1. Pre- perception, social capital, and healthy house condition

2. Health education

3. Post-perception, social capital, and healthy house condition 4. Analysis

Figure 2: The research flow [25]

according to the community meeting schedule for 3 months (December 2018-February 2019).

\section{Research instrument}

The data collection instrument in this research was a questionnaire that had passed the validity and reliability tests. The applied validity test in this research was construct validity by calculating the correlation between the research data and the existing measurement. The minimum standard for the validity measurement was based on the Pearson correlation $\geq$ of 0.30 [25], [26]. The validity test was conducted by testing the questionnaire to minimally $10 \%$ of the total respondents. In this research, the questionnaire was tested on 80 respondents (30\%) [27]. The results of the validity and reliability tests are presented in Table 1.

The questionnaire consisted of three sections: Perceptions of DHF, perceptions of DHF control, and social capital. Every item in the questionnaire had passed the validity test as the score of Pearson correlation $>0.30$ and $p<0.05$. Similarly, all items of the questionnaire were valid according to the Spearman reliability test. The reliability test showed that the Alpha Cronbach's score was $>0.60$, which means that the questionnaire was considered valid and reliable [26]. To measure the healthy house condition, a checklist based on the Ministry of Health of the Republic of Indonesia in 2002 was used.

\section{Data collection and analysis}

Data were collected using the same questionnaire and checklist for pre- and post-tests. The pre-data were taken in November 2018 and the post-data were taken in August 2019. The interval between the implementation of the intervention and the post-data collection was 6 months to see the consistency of changes [28]. The data obtained were analyzed by employing SPSS 24 using the Wilcoxon test because the data were not normally distributed [29].

\section{Results}

\section{Participants' socio-demographic}

Table 2 lists the socio-demographics of the respondents in the research setting. The respondents were dominated by women $(77.54 \%)$. The predominant occupation was housewife $(49.8 \%)$ with the most common age range being more than 45 years $(58.88 \%)$. The majority of the participants' education was in senior high school (40.45\%).

\section{Perception of DHF pre- and post-intervention}

Perception of DHF is what the community thought about DHF. The data from the perception about DHF measurement show $100 \%$ improvement on how the community perceived DHF as a disease that has to be eradicated (Table 3 )

Wilcoxon test shows that the average perception of DHF before and after health education had a significant difference with $p=0.000$ (Table 4). It was found that there was an improvement in the mean of the perception of DHF before and the $6^{\text {th }}$ month after the health education. 
Table 1: The results of validity and reliability tests

\begin{tabular}{|c|c|c|c|}
\hline Variable & Item & $\begin{array}{l}\text { Pearson correlation } \\
\text { (Validity test) }\end{array}$ & $\begin{array}{l}\text { Alpha Cronbach } \\
\text { (Reliability test) }\end{array}$ \\
\hline Perception of & 1 & 0.35 (valid) & $0.724 /$ reliable \\
\hline \multirow[t]{9}{*}{ DHF } & 2 & 0.34 (valid) & \\
\hline & 3 & 0.31 (valid) & \\
\hline & 4 & 0.48 (valid) & \\
\hline & 5 & 0.44 (valid) & \\
\hline & 6 & 0.59 (valid) & \\
\hline & 7 & 0.55 (valid) & \\
\hline & 8 & 0.57 (valid) & \\
\hline & 9 & 0.51 (valid) & \\
\hline & 10 & 0.48 (valid) & \\
\hline Perception of & 1 & 0.35 (valid) & $0.796 /$ reliable \\
\hline \multirow[t]{18}{*}{ DHF control } & 2 & 0.37 (valid) & \\
\hline & 3 & 0.48 (valid) & \\
\hline & 4 & 0.45 (valid) & \\
\hline & 5 & 0.33 (valid) & \\
\hline & 6 & 0.55 (valid) & \\
\hline & 7 & 0.70 (valid) & \\
\hline & 8 & 0.36 (valid) & \\
\hline & 9 & 0.44 (valid) & \\
\hline & 10 & 0.34 (valid) & \\
\hline & 11 & 0.49 (valid) & \\
\hline & 12 & 0.53 (valid) & \\
\hline & 13 & 0.49 (valid) & \\
\hline & 14 & 0.61 (valid) & \\
\hline & 15 & 0.38 (valid) & \\
\hline & 16 & 0.59 (valid) & \\
\hline & 17 & 0.51 (valid) & \\
\hline & 18 & 0.35 (valid) & \\
\hline & 19 & 0.37 (valid) & \\
\hline \multicolumn{4}{|l|}{ Social capital } \\
\hline A. & 1 & 0.46 (valid) & 0.683/reliable \\
\hline \multirow[t]{8}{*}{ Participation } & 2 & 0.33 (valid) & \\
\hline & 3 & 0.35 (valid) & \\
\hline & 4 & 0.56 (valid) & \\
\hline & 5 & 0.38 (valid) & \\
\hline & 6 & 0.45 (valid) & \\
\hline & 7 & 0.56 (valid) & \\
\hline & 8 & 0.31 (valid) & \\
\hline & 9 & valid) & \\
\hline \multirow[t]{9}{*}{ B. Concern } & 1 & 0.78 (valid) & 0.793/reliable \\
\hline & 2 & 0.61 (valid) & \\
\hline & 3 & 0.55 (valid) & \\
\hline & 4 & 0.67 (valid) & \\
\hline & 5 & 0.57 (valid) & \\
\hline & 6 & 0.63 (valid) & \\
\hline & 7 & 0.63 (valid) & \\
\hline & 8 & 0.40 (valid) & \\
\hline & 9 & valid) & \\
\hline \multirow[t]{5}{*}{ C. Trust } & 1 & 0.71 (valid) & $0.636 /$ reliable \\
\hline & 2 & 0.35 (valid) & \\
\hline & 3 & 0.64 (valid) & \\
\hline & 4 & 0.42 & \\
\hline & & (valid) & \\
\hline D. Social & 1 & 0.69 (valid) & $0.813 /$ reliable \\
\hline \multirow[t]{4}{*}{ norm } & 2 & 0.60 (valid) & \\
\hline & 3 & 0.64 (valid) & \\
\hline & 4 & 0.77 (valid) & \\
\hline & 5 & A.79 (valid) & \\
\hline E. Readiness & 1 & 0.47 (valid) & 0.633/reliable \\
\hline to learn new & 2 & 0.61 (valid) & \\
\hline \multirow[t]{3}{*}{ ideas } & 3 & 0.34 (valid) & \\
\hline & 4 & 0.68 (valid) & \\
\hline & 5 & 0.43 (valid) & \\
\hline
\end{tabular}

DHF: Dengue hemorrhagic fever.
Table 2: Socio-demographic of research respondents $(n=267)$

\begin{tabular}{lll}
\hline & Frequency & Percentage \\
\hline Gender & & \\
Male & 60 & 22.47 \\
$\quad$ Female & 207 & 77.54 \\
Occupation & & \\
$\quad$ Not working & 3 & 1.12 \\
Housewife & 133 & 49.8 \\
Self-employed & 91 & 34.08 \\
$\quad$ Others & 40 & 14.98 \\
Ages & & \\
17-25 & 13 & 4.48 \\
$26-35$ & 34 & 12.73 \\
$36-45$ & 63 & 23.59 \\
$>45$ & 157 & 58.88 \\
Education & & 1.87 \\
No School & 5 & 19.10 \\
Elementary School & 51 & 17.98 \\
Junior High School & 48 & 40.45 \\
Senior High School & 108 & 6.37 \\
Diploma & 17 & 14.23 \\
z.37omaHi & 38 & \\
\hline
\end{tabular}

\section{Social capital pre and post-intervention}

Social capital holds five components, namely, participation, concern, trust, social norms, and readiness in learning new ideas [11]. Of the five components, there are changes after the intervention (Table 7). This difference is statistically significant with $p=0.003$ for participation, $p=0.000$ for trust, and $p=0.000$ for readiness to learn new ideas. Participation and social norms did not show any significant difference with $p>0.005$ (Table 7).

Table 3: Perception of DHF $(n=267)$

\begin{tabular}{|c|c|c|c|c|}
\hline \multirow[t]{3}{*}{ Perception of DHF } & \multicolumn{2}{|l|}{ Pre } & \multicolumn{2}{|l|}{ Post } \\
\hline & $\mathrm{n}(\%)$ & $\mathrm{n}(\%)$ & $\mathrm{n}(\%)$ & $\mathrm{n}(\%)$ \\
\hline & Agree & Disagree & Agree & Disagree \\
\hline $\begin{array}{l}\text { Dengue hemorrhagic fever is a } \\
\text { disease transmitted by the Aedes } \\
\text { aegypti }\end{array}$ & $263(98.5)$ & $4(1.5)$ & $264(98.9)$ & $3(1.1)$ \\
\hline $\mathrm{DHF}$ is a fatal disease & $261(97.8)$ & $6(2.2)$ & $262(98.1)$ & $5(1.9)$ \\
\hline $\begin{array}{l}\text { DHF is a disease that must be } \\
\text { eradicated }\end{array}$ & $265(99.2)$ & $2(0.8)$ & $267(100)$ & $0(0)$ \\
\hline $\begin{array}{l}\text { Eradicating dengue fever is an } \\
\text { obligation of health officers only }\end{array}$ & $213(79.8)$ & $54(20.2)$ & $214(80.2)$ & $53(19.8)$ \\
\hline $\begin{array}{l}\text { People do not need to participate } \\
\text { in the dengue eradication effort }\end{array}$ & $233(87.3)$ & $34(12.7)$ & $235(88)$ & $32(22)$ \\
\hline $\begin{array}{l}\text { I would be partially responsible for } \\
\text { any neighbor who suffered from } \\
\text { dengue fever }\end{array}$ & $216(80.9)$ & $51(19.1)$ & $217(81.3)$ & $50(18.7)$ \\
\hline $\begin{array}{l}\text { Having a family member who } \\
\text { suffers from dengue fever would } \\
\text { cost expensive treatment }\end{array}$ & 257 (96.3) & $10(3.7)$ & $259(97)$ & $8(3)$ \\
\hline Everyone is possible to suffer DHF & $262(98.1)$ & $5(1.9)$ & $264(98.9)$ & $3(3.3)$ \\
\hline $\begin{array}{l}\text { DHF transmission can occur in } \\
\text { every place and at any time }\end{array}$ & 248 (92.9) & $19(7.1)$ & 249 (93.3) & $18(6.7)$ \\
\hline $\begin{array}{l}\text { We must always be aware of the } \\
\text { transmission of dengue disease }\end{array}$ & 263 (98.5) & $4(1.5)$ & 264 (98.9) & $3(3.3)$ \\
\hline
\end{tabular}
DHF: Dengue hemorrhagic fever.

\section{Healthy house pre- and post-intervention}

A healthy house as one of the risk factors for dengue transmission holds three components, namely, the parts of the house, sanitation facilities,

Table 4: The effectiveness of health education for the perception of DHF

\begin{tabular}{llll}
\hline Variables & Average & Average & Difference (p-value) \\
& Pre \pm SD & Post \pm SD & \\
\hline Perception of DHF & $92.99 \pm 10.48$ & $96.14 \pm 6.69$ & $0.000^{*}$ \\
& Negative rank $=46$ & & \\
& Positive rank $=93$ & & \\
& Ties $=128$ & & \\
& &
\end{tabular}

and occupant behaviors. Table 8 shows that after the health education intervention, the average score of the 
parts of a healthy house improved. This difference was statistically significant with $p=0.000$ for physical parts of the house, $p=0.017$ for sanitation facilities, and $p=0.000$ for occupant behavior (Table 8).

Table 5: Perceptions of DHF control $(n=267)$

\begin{tabular}{|c|c|c|c|c|}
\hline \multirow[t]{3}{*}{ Perception of dengue fever control } & \multicolumn{2}{|l|}{ Pre } & \multicolumn{2}{|l|}{ Post } \\
\hline & $\mathrm{n}(\%)$ & $\mathrm{n}(\%)$ & $\mathrm{n}(\%)$ & $\mathrm{n}(\%)$ \\
\hline & Agree & Disagree & Agree & Disagree \\
\hline $\begin{array}{l}\text { Dengue is a disease that must be } \\
\text { controlled together }\end{array}$ & $265(99.2)$ & $2(2.2)$ & $267(100)$ & $0(0)$ \\
\hline $\begin{array}{l}\text { Eradicating dengue is the task of health } \\
\text { workers only }\end{array}$ & $212(79.4)$ & $55(20.6)$ & $213(79.8)$ & $54(20.2)$ \\
\hline $\begin{array}{l}\text { The community plays an important role } \\
\text { in the DHF eradication }\end{array}$ & $255(95.5)$ & $12(4.5)$ & $256(95.8)$ & $11(4.2)$ \\
\hline $\begin{array}{l}\text { I will allow the Jumantik to observe the } \\
\text { larvae at my house }\end{array}$ & $260(97.4)$ & $7(2.6)$ & 262 (98.1) & $5(1.9)$ \\
\hline $\begin{array}{l}\text { I feel embarrassed if there were any } \\
\text { larvae at my house }\end{array}$ & $156(58.4)$ & $111(41.6)$ & $158(59.2)$ & $109(40.9)$ \\
\hline $\begin{array}{l}\text { I feel uncomfortable if a Jumantik officer } \\
\text { checks my house }\end{array}$ & $227(85)$ & 40) 15) & $229(85.8)$ & $38(14.2)$ \\
\hline $\begin{array}{l}\text { I don't like when my house is inspected } \\
\text { by Jumantik officer }\end{array}$ & $242(90.6)$ & $25(9.4)$ & 244 (91.4) & $23(8.6)$ \\
\hline $\begin{array}{l}\text { I am worried if my water tank is sprinkled } \\
\text { with abate }\end{array}$ & $209(78.3)$ & $58(21.7)$ & $211(79)$ & $56(21)$ \\
\hline Abate is poisonous & $218(81.6)$ & $49(18.4)$ & $220(82.4)$ & $47(17.6)$ \\
\hline $\begin{array}{l}\text { Fogging or spraying is the most } \\
\text { effective way to eradicate DHF }\end{array}$ & $177(66.9)$ & $90(33.7)$ & $178(66.7)$ & $89(33.3)$ \\
\hline $\begin{array}{l}\text { I support the eradication of dengue by } \\
\text { fogging because it is easy and practical }\end{array}$ & $163(61.0)$ & $104(39.0)$ & $164(61.4)$ & $103(38.6)$ \\
\hline $\begin{array}{l}\text { Efforts to eradicate dengue with } 3 \mathrm{M} \\
\text { (draining, closing, and managing used } \\
\text { goods) is troublesome }\end{array}$ & $207(77.5)$ & $60(22.5)$ & $209(78.3)$ & $58(21.7)$ \\
\hline $\begin{array}{l}\text { I don't like the activity of mosquito nest } \\
\text { eradication }\end{array}$ & $229(85.8)$ & $38(14.2)$ & $231(86.5)$ & $36(13.5)$ \\
\hline $\begin{array}{l}\text { I don't have any spare time to eradicate } \\
\text { mosquito nests (PSN) }\end{array}$ & $224(83.9)$ & $43(16.1)$ & $225(84.3)$ & $42(15.7)$ \\
\hline $\begin{array}{l}\text { I can pay someone else to eradicate the } \\
\text { mosquito nests when I'm busy }\end{array}$ & $61(22.8)$ & $206(77.2)$ & $61(22.8)$ & $206(77.2)$ \\
\hline $\begin{array}{l}\text { I will not sprinkle larvicide powder (abate) } \\
\text { from the officer into my wells or other } \\
\text { clean water tanks }\end{array}$ & $185(69.3)$ & $82(30.7)$ & $186(69.7)$ & $81(30.3)$ \\
\hline $\begin{array}{l}\text { I make sure that my house is free from } \\
\text { any mosquito nest }\end{array}$ & $259(95.9)$ & $8(4.1)$ & $261(97.8)$ & $6(2.2)$ \\
\hline Eradication of DHF is my responsibility & $232(86.9)$ & $35(13.1)$ & $234(87.6)$ & $33(12.4)$ \\
\hline $\begin{array}{l}\text { Cooperation in the DHF eradication is } \\
\text { very important }\end{array}$ & $263(98.5)$ & $4(1.5)$ & $265(99.2)$ & $2(0.8)$ \\
\hline
\end{tabular}

\section{Discussion}

The majority of participants in this study were housewives with high school education backgrounds and age over 45 years (Table 2). The dominance of women in the effort of DHF control is notably high in Indonesia. In Indonesia, gender division of labor is common. Women are assigned to do domestic work while men do nondomestic work such as earning money [30], [31]. Efforts to control DHF at the house, such as draining water containers, cleaning the house, and preserving the house free of mosquito larvae, are considered domestic work that is performed by women [30], [31], [32].

Table 6: The effectiveness of health education for the perception of DHF control

\begin{tabular}{|c|c|c|c|}
\hline \multirow[t]{2}{*}{ Variables } & Average & Average & \multirow[t]{2}{*}{ Difference (p-value) } \\
\hline & Pre \pm SD & Post \pm SD & \\
\hline \multirow[t]{3}{*}{ Perception of DHF control } & \multicolumn{3}{|c|}{ Negative rank $=79$} \\
\hline & \multicolumn{3}{|c|}{ Positive rank = 143} \\
\hline & \multicolumn{3}{|l|}{ Ties $=45$} \\
\hline
\end{tabular}

This study was aimed to assess the effect of providing health education about DHF on changes in the community's perceptions, social capital, and healthy house conditions. The wrong perception about DHF could influence the knowledge, attitudes, and practices of DHF control [17], [33], [34].

Table 7: The effectiveness of health education for social capital ( $n=267$ )

\begin{tabular}{llll}
\hline Social Capital & $\begin{array}{l}\text { Pre } \\
\text { Average } \pm \mathrm{SD}\end{array}$ & $\begin{array}{l}\text { Post } \\
\text { Average } \pm \text { SD }\end{array}$ & Difference (p-value) \\
\hline Participation & $81.9 \pm 38.1$ & $83.5 \pm 15.0$ & 0.247 \\
Concern & $86.5 \pm 11.1$ & $89.3 \pm 9.6$ & $0.003^{*}$ \\
Trust & $74.5 \pm 20.4$ & $80.2 \pm 18.3$ & $0.000^{*}$ \\
Social norm & $37.5 \pm 30.1$ & $39.6 \pm 31.3$ & 0.462 \\
Readiness to learn new ideas & $83.7 \pm 17.5$ & $89.1 \pm 14.3$ & $0.000^{*}$ \\
\hline "Significant, SD: Standard deviation. & & &
\end{tabular}

Perception is obtained from stimuli that enter through the five senses and then are processed in the brain to give rise to an assessment. Accordingly, if the received stimulus is translated incorrectly because of the lack of information conveyed, it can affect a person's view of DHF [15], [35]. So far, what has developed in the community is the reluctance to carry out DHF control because there are health workers who are responsible for this and if there are cases of DHF, they can ask for fogging. According to most people, fogging is the best and quickest way to control DHF so that many community-based DHF control programs often fail in their other efforts [36], [37]. Informative health education about DHF can improve public perceptions of DHF, demonstrating that DHF is a dangerous disease that can be contagious and cause death, and besides that, the task of controlling dengue is the task of all components of society and cannot only be done by health workers (Table 3) [9], [15], [38], [39].

Table 8: The effectiveness of health education for healthy house $(n=267)$

\begin{tabular}{llll}
\hline Healthy house & $\begin{array}{l}\text { Pre } \\
\text { Average } \pm \text { SD }\end{array}$ & $\begin{array}{l}\text { Post } \\
\text { Average } \pm \text { SD }\end{array}$ & Difference (p-value) \\
\hline $\begin{array}{l}\text { Physical parts of the house (Roofs, } 212.9 \\
\text { windows, walls, floors, ventilation, }\end{array}$ & 223.3 & $0.000^{*}$ \\
$\begin{array}{l}\text { kitchen chimneys, and lighting) } \\
\text { Sanitation facilities (Clean water } \\
\text { facilities, Source of clean water, }\end{array}$ & 294.7 & 304.9 & $0.017^{*}$ \\
$\begin{array}{l}\text { Toilet, Type of latrine, Wastewater } \\
\text { disposal facilities, Garbage } \\
\text { disposal facility, Type of trash can, } \\
\text { and Waste management) }\end{array}$ & & \\
$\begin{array}{l}\text { Occupant behavior (Open the } \\
\text { window, Clean house, and yard, }\end{array}$ & & \\
and the habit of Taking out the \\
trash)
\end{tabular}

Social capital consists of components of participation, concern, trust, social norms, and readiness to learn new ideas, and all of these components support each other in efforts to control DHF [28], [29], [30]. The implementation of health promotion depends on the social capital of a community but health promotion can strengthen the social capital of the community. The existence of the same goals that are conducted in controlling DHF, the interaction between individuals, community leaders, and health workers to increase participation, cooperation, mutual trust, and the desire to learn new things in DHF control can strengthen the social capital component [40], [41], [42], [43]. Health education is always followed by other community activities which are more easily accepted and provide a good relationship between participants and researchers. Good social relations and health education that are well 
received by the research participants can change their participation, concern, trust, social norms, and readiness to learn new information about DHF control for the better. This good change has also occurred due to the participation of the local village government and Puskesmas during the implementation of health education. They support the participants to take part in health education concerning prevention of DHF [9], [20], [44], [45].

A healthy house is one of the environmental factors that influence the transmission of DHF since the A. aegypti mosquito is an anthropophilic mosquito. The $A$. aegypti breeding occurs in settlements. The condition of the house can be a supporting habitat for the $A$. aegypti mosquitoes. The physical condition of the house, sanitation facilities, and the behavior of the occupants of the house determine the condition of the house [44], [45], [46]. The poor physical conditions of the house, such as low lighting and high humidity, are supportive of the breeding of the $A$. aegypti, which like dark and humid places, so these conditions should be minimized in the house [44], [47], [48], [49]. Sanitation facilities such as the availability of sufficiently clean water, so that people do not need to collect water, would reduce the mosquito's breeding places [50], [51], [52], [53]. The availability of waste processing facilities at the house could reduce the disposable site of $A$. aegypti [22], [54]. Occupant behavior greatly affects the condition of the house. The habit of maintaining cleanliness, avoiding hanging clothes, and other habits could be supportive and preventive for mosquito breeding [21], [55]. This must be known by the community so that they could maintain the condition of their houses from being the breeding spots to the $A$. aegypti mosquitoes, through health education, information, and knowledge about DHF are provided so that public awareness increases [3], [24], [56], [57].

Health education about DHF affects perceptions, capital, and healthy house conditions. Post-intervention data were taken 6 months after the health education was done and the results still showed positive changes in all variables [58]. These changes are consistent. Health education that is given repeatedly over a long enough period influences the community's understanding of DHF and its transmission risk factors [3], [59], [60]. DHF is a disease that is often neglected [18], especially at this time when most people are focused on efforts of COVID19 control, including in Indonesia. DHF cases remain high and become the second most significant threat after COVID-19 [61], [62]. DHF control in Indonesia is still very dependent on larva investigators, health workers, and fogging officers. Since the role of the community has not been maximal in DHF controlling efforts, more community-based DHF control is needed [7], [42], [52], [63]. Continuous health education is important to remind the community about the dengue problem and the shared responsibility in DHF controlling efforts. Regular health education can increase public awareness to participate in controlling DHF. The health education also can involve the Puskesmas as the closest health service facility to the community and involve the village government for monitoring and evaluating the implementation and results of the interventions. Besides, the Puskesmas and the village government would be responsible for the sustainability of health education to the community after the research concludes. This is essential because health education must be presented continuously to maintain the community's consistency in controlling DHF. The limitation of this study is that the assessment process after the intervention was not done every month so that the changes that occurred every month could not be known, but the assessment conducted at the $6^{\text {th }}$ month still showed that the changes that occurred after health education were consistently good.

\section{Conclusion}

Health education can increase good perceptions about DHF and its control, social capital, and healthy housing conditions. It is very important to increase the active participation of the community in implementing DHF control. The implementation of this health education needs to be done continuously to maintain the consistency of changes that occur in the community. It is feasible by involving the community health centers (Puskesmas) and the village government as managers of the health education program about dengue after the research is conducted.

\section{Data Availability}

All the data analyzed for this study are included within the article.

\section{Ethical Approval}

This research had received approval from the Medical and Health Research Ethics Committee of FKKMK UGM number: KE/FK/1233/EC/2018 accepted on November 22, 2018.

\section{Authors Contributions}

Idea owner of this study: (TWS), (TBTS), (MAW), (EHM), and (RSP). 
Study design: TWS, TBTS, MAW, EHM, and

RSP.

Data gathering: TWS.

Writing and submitting manuscript: TWS and

RSP.

\section{Acknowledgments}

This paper is dedicated to the late Dr. dr. Mahardika Agus Wijayanti, DTM and H, M.Kes. for his contribution to this research.

My sincere gratitude goes to:

1. LPDP The Ministry of Finance of the Republic of Indonesia.

2. All the participants.

\section{References}

1. Codeço C, Lima AW, Araújo SC, Lima JB, Maciel-de-Freitas R, Honório NA, et al. Surveillance of Aedes aegypti: Comparison of house index with four alternative traps. PLoS Negl Trop Dis. 2015;9(2):e0003475. https://doi.org/10.1371/journal. pntd. 0003475

PMid:25668559

2. de Abreu FV, Morais MM, Ribeiro SP, Eiras ÁE. Influence of breeding site availability on the oviposition behaviour of Aedes aegypti. Mem Inst Oswaldo Cruz. 2015;110(5):669-76. https:// doi.org/10.1590/0074-02760140490

PMid:26154742

3. Kusuma Y, Burman D, Kumari R, Lamkang A, Babu B. Impact of health education based intervention on community's awareness of dengue and its prevention in Delhi, India. Glob Health Promot. 2019;26(1):50-9. https://doi.org/10.1177/1757975916686912

PMid:28349734

4. DIY DKP. DHF Cases in Yogyakarta. Yogyakarta: DIY DKP 2020.

5. Sleman District Health Office. DHF Cases in Sleman Yogyakarta. Yogyakarta: Sleman District Health Office; 2019. https://doi. org/10.26911/theicph.2019.02.30

6. Rakhmani AN, Limpanont Y, Kaewkungwal J, Okanurak K. Factors associated with dengue prevention behaviour in Lowokwaru, Malang, Indonesia: A cross-sectional study. BMC Public Health. 2018;18(1):619. https://doi.org/10.1186/ s12889-018-5553-z

PMid:29751758

7. Sulistyawati S, Astuti F, Umniyati S, Satoto T, Lazuardi L, Nilsson $\mathrm{M}$, et al. Dengue vector control through community empowerment: Lessons learned from a community-based study in Yogyakarta, Indonesia. Int J Environ Res Public Health. 2019;16(6):1013. https://doi.org/10.3390/ijerph16061013 PMid:30897770

8. Tana S, Umniyati S, Petzold M, Kroeger A, Sommerfeld J Building and analyzing an innovative community-centered dengue-ecosystem management intervention in Yogyakarta,
Indonesia. Pathog Glob Health. 2012;106(8):469-78. https://doi. org/10.1179/2047773212y.0000000062

PMid:23318239

9. Suwanbamrung C. Community capacity for sustainable community-based dengue prevention and control: Domain, assessment tool and capacity building model. Asian Pac J Trop Med. 2010;3(6):499-504. https://doi.org/10.1016/ s1995-7645(10)60121-6

10. Spiegel J, Breilh J, Wilches A, Mitchell-Foster K, Delgado J. Integrating participatory community mobilization processes to improve dengue prevention: An eco-bio-social scaling up of local success in. J Trans R Soc Trop Med Hyg. 2015;109(6):419. https://doi.org/10.1093/trstmh/trv028 PMid:25890933

11. Gudmundsson G, Mikiewicz P. The concept of social capital and its usage in educational studies. In: Studia Edukacyjne. $1^{\text {st }}$ ed. Poland: Adam Mickiewicz University Press; 2012. p. 55-79.

12. Eriksson M. Social Capital, Health and Community Action. Social Capital, Health and Community Action Implications for Health Promotion; 2010. p. 17-44. https://doi.org/10.3402/gha. v4i0.5611

13. Akintunde E. Theories and concepts for human behavior in environmental preservation. J Environ Sci Public Health 2017;1:120-33.

14. Andersson N, Nava-Aguilera E, Arosteguí J, Morales-Perez A, Suazo-Laguna $\mathrm{H}$, Legorreta-Soberanis $\mathrm{J}$, et al. Evidence based community mobilization for dengue prevention in Nicaragua and Mexico (Camino Verde, the Green Way): Cluster randomized controlled trial. BMJ 2015;351:h3267. https://doi.org/10.1136/ bmj.h3267

PMid:26156323

15. Ibarra AM, Luzadis VA, Cordova MJB, Silva M, Ordoñez $T$, Ayala EB, et al. A social-ecological analysis of community perceptions of dengue fever and Aedes aegypti in Machala, Ecuador. BMC Public Health 2014;14(1135):1135. https://doi. org/10.1186/1471-2458-14-1135

PMid:25370883

16. Ibarra A, Ryan SJ, Beltrán E, Mejía R, Silva M, Muñoz Á Dengue vector dynamics (Aedes aegypti) influenced by climate and social factors in ecuador: Implications for targeted control. PLoS One. 2013;8(11):e78263. https://doi.org/10.1371/journal. pone.0078263

PMid:24324542

17. Rakhmani AN, Okanurak K, Kaewkungwal J, Limpanont $Y$ Knowledge, perception, and dengue prevention behavior in lowokwaru sub district, urban area in Malang, Indonesia. J Adv Heal Med Sci. 2017;3(1):17-26. https://doi.org/10.20474/ jahms3.1.3

18. Frank AL, Beales ER, de Wildt G, Meza Sanchez G, Jones LL. We need people to collaborate together against this disease: A qualitative exploration of perceptions of dengue fever control in caregivers' of children under 5 years, in the Peruvian Amazon. PLoS Negl Trop Dis. 2017;11(9):e0005755. https://doi. org/10.1371/journal.pntd.0005755 PMid:28873408

19. Ogden J, Morrison K, Hardee K. Social capital to strengthen health policy and health systems. Health Policy Plan. 2014;29(8):1075-85. https://doi.org/10.1093/heapol/czt087 PMid:24277736

20. Asri, Nuntaboot K, Festi P. Community social capital on fighting dengue fever in suburban Surabaya, Indonesia: A qualitative study. Int J Nurs Sci. 2017;4(4):374-7. https://doi.org/10.1016/j. ijnss.2017.10.003 PMid:31406780

21. Hariyono H, Suyadi S, Hakim L, Yanuwiadi B. The role of 
environmental and behavior factors to dengue fever incidents. J Appl Environ Biol Sci. 2016;6(4):1-8.

22. Getachew D, Tekie H, Gebre-Michael T, Balkew M, Mesfin A. Breeding sites of Aedes aegypti: Potential dengue vectors in dire Dawa, East Ethiopia. Interdiscip Perspect Infect Dis. 2015;2015:706276. https://doi.org/10.1155/2015/706276 PMid:26435712

23. Bota R, Ahmed M, Salah M, Aziz A. Knowledge, attitude and perception regarding dengue fever among university students of interior Sindh. J Infect Public Health. 2014;7(3):218-23. https:// doi.org/10.1016/j.jiph.2013.11.004

PMid:24613408

24. Sumitro $\mathrm{S}$, Kusnanto $\mathrm{H}$, Istiono W. The Effect of lecture and small group discussion method in health education towards dengue haemorrhagic fever vector larva free proportion in Gunungkidul Regency. Rev Prim Care Pract Educ (Kajian Prakt dan Pendidik Layanan Prim 2019;2(1):25-31. https://doi. org/10.22146/rpcpe.44471

25. Baum FE. Power and glory: Applying participatory action research in public health. Gac Sanit. 2016;30(6):405-7. https:// doi.org/10.1016/j.gaceta.2016.05.014

PMid:27491431

26. Budiastuti D, Bandur A. Research Validity and Reliability. $1^{\text {st }}$ ed. Jakarta: Mitra Wacana Media; 2018. p. 169-73.

27. Alwi I. Empirical criteria in determining sample size. Form J IIm Pendidik MIPA. 2012;2(2):140-8.

28. Lally P, Jaarsveld C, Potts H, Wardle J. How are habits formed: Modelling habit formation in the real world. Eur J Soc Psychol Eur. 2010;40:625-34. https://doi.org/10.1002/ejsp.674

29. Imam A, Mohammed U, Moses Abanyam C. On consistency and limitation of paired t-test, sign and wilcoxon sign rank test. IOSR J Math. 2014;10(1):1-6. https://doi.org/10.9790/5728-10140106

30. Chanyasanha C, Han M, Teetipsatit S. Dengue hemorrhagic fever knowledge, perception, and preventive behavior among secondary school students in Bangkok. J Med Assoc Thai. 2013;96(5):14-24.

PMid:24851569

31. Tandos R. Empowering Indonesian female domestic workers. J IImu Dakwah. 2014;34(2):181-96. https://doi.org/10.21580/ jid.34i.2.53

32. Pujiyanti A, Trapsilowati W. Knowledge, attitudes and behaviors of housewives in preventing dengue fever in Kutowinangun Village, Salatiga. J Vektora. 2014;2(2):102-15.

33. Waruwu MK, Sukartini T, Indarwati R. The Relationship between knowledge and motivation and mother behavior in eradicating mosquito nests (PSN) DBD. Prodi Ners. 2014;1(1):43-51.

34. Irianty $\mathrm{H}$, Agustina $\mathrm{N}$, Safitri AP. Relationship between attitudes and prevention efforts of mothers with the incidence of dengue hemorrhagic fever (DHF) in the work area of Guntung Payung community health center. Publ Kesehat Masy Indones. 2015;4(2):44-8.

35. Ebu NI, Amissah-Essel S, Asiedu C, Akaba S, Pereko KA. Impact of health education intervention on knowledge and perception of cervical cancer and screening for women in Ghana. BMC Public Health. 2019;19(1):1505. https://doi. org/10.1186/s12889-019-7867-x

PMid:31711469

36. Dijksterhuis A, Knippenberg A. The relation between perception and behavior, or how to win a game of trivial pursuit the relation between perception and behavior, or how to win a game of trivial pursuit. J Personal Soc Psychol. 2016;74(4):865-77. https://doi. org/10.4324/9780203496398-16 PMid:9569649

37. Ward M, Grinstein G, Keim D. Human perception and information processing. In: Interactive Data Visualization: Foundations,
Techniques and Applications. Boca Raton, Florida: CRC Press; 2015. p. 93-5. https://doi.org/10.1201/b10683

38. Trisnaniyanti I, Prabandari Y, Citraningsih. Perception and activities of PSN DBD cadres on the prevention and eradication of dengue hemorrhagic fever. Ber Kedokt Masy. 2010;26(3):132-7.

39. Azam M, Azinar M, Ika F. Needs analysis and designing "ronda jentik" as a model for community empowerment in eradicating mosquito nests. Unnes J Public Health 2015;4(1):54-60.

40. Simanjuntak R, Farchanny. 1 House 1 jumantik movement a call for action. e-Health Bull. 2017;11:5-6.

41. Baldacchino F, Caputo B, Chandre F, Rizzoli A. Control methods against invasive Aedes mosquitoes in Europe: A review. Pest Manag Sci. 2015;71(11):1471-85. https://doi.org/10.1002/ ps.4044 PMid:26037532

42. Miyamoto K, Iwakuma M, Nakayama T. Social capital and health: Implication for health promotion by lay citizens in Japan. Glob Health Promot. 2015;22(4):5-19. https://doi. org/10.1177/1757975914547547

PMid:25319376

43. Eriksson M. Social capital and health--implications for health promotion. Glob Health Action. 2011;4:5611. https://doi. org/10.3402/gha.v4i0.5611

PMid:21311607

44. Conyer T, Galván J, Zuniga P. Community participation in the prevention and control of dengue: the patio limpio strategy in Mexico. Paediatr Int Child Health 2012;32(Suppl 1):10-3.

PMid:22668443

45. Khun S, Manderson L. Community participation and social engagement in the prevention and control of dengue fever in rural Cambodia. Dengue Bull. 2016;32:145-55.

46. Wanti, Yudhastuti R, Notobroto H, Subekti S, Sila O, Kristina R, et al. Dengue haemorrhagic fever and house conditions in Kupang City, East Nusa Tenggara Province. Kesmas Natl Public Health J. 2019;13(4):177. https://doi.org/10.21109/kesmas. v13i4.2701

47. Satoto TB, Pascawati NA, Wibawa T, Frutos R, Maguin S, Mulyawan IK, et al. Entomological index and home environment contribution todengue hemorrhagic fever in Mataram City, Indonesia. Kesmas. 2020;15(1):32-9. https://doi.org/10.21109/ kesmas.v15i1.3294

48. Wijirahayu S, Sukesi TW. The relationship between physical environmental conditions and the incidence of dengue hemorrhagic fever in the work area of Puskesmas Kalasan, Sleman Regency. J Kesehat Lingkung Indones. 2019;18(1):19. https://doi.org/10.14710/jkli.18.1.19-24

49. Ridha MR, Rahayu N, Rosvita NA, Setyaningtyas DE. The relation of environmental condition and container to the existance of the Aedes aegypti larvae in dengue haemorrhagic fever in endemic area Banjarbaru. Epidemiol Penyakit Bersumber Binatang. 2013;4(3):133-7

50. Astuti, Elisabeth DL. Relationship of physical environmental conditions to the density level of Aedes sp larvae in elementary schools of kasihan subdistrict, Bantul, special region of Yogyakarta. J IImu Kesehat Masy. 2018;9(3):216-25.

51. García-Betancourt T, Higuera-Mendieta DR, González-Uribe C, Cortés S, Quintero J. Understanding water storage practices of urban residents of an endemic dengue area in Colombia: Perceptions, rationale and socio-demographic characteristics. PLoS One. 2015;10(6):e0129054. https://doi.org/10.1371/ journal.pone. 0129054

PMid:26061628

52. Abeyewickreme $W$, Wickremasinghe $A R$, Karunatilake $K$, Sommerfeld J, Axel K. Community mobilization and household level waste management for dengue vector control in Gampaha district of Sri Lanka; an intervention study. Pathog Glob 
Health. 2012;106(8):479-87. https://doi.org/10.1179/20477732 $12 \mathrm{y} .0000000060$

PMid:23318240

53. Arunachalam N, Tyagi B, Samuel M, Krishnamoorthi R, Manavalan R, Tewari S, et al. Community-based control of Aedes aegypti by adoption of eco-health methods in Chennai City, India. Pathog Glob Health. 2012;106(8):488-96. https://doi. org/10.1179/2047773212y.0000000056 PMid:23318241

54. Nofita E, Rusdji SR, Irawati N. Analysis of indicators entomology Aedes aegypti in endemic areas of dengue fever in Padang, West sumatra, Indonesia. Int J Mosq Res. 2017;4(2):57-9.

55. Tambo E, El Dessouky AG, Khater El. Innovative preventive and resilience approaches against aedes-linked vectorborne arboviral diseases threat and epidemics burden in Gulf Council Countries. Oman Med J. 2019;34(5):391-6. https://doi. org/10.5001/omj.2019.73 PMid:31555414

56. Satoto T, Diptyanusa A, Setiawan Y, Alvira N. Environmental factors of the home affect the density of Aedes aegypti (Diptera: Culicidae). J Kedokt Yars. 2017;25(1):41-51.

57. Arneliwati, Agrina, Dewi A. The effectiveness of health education using audiovisual media on increasing family behavior in preventing dengue hemorrhagic fever (DHF). Enferm Clin. 2019;29(2013):30-3. https://doi.org/10.1016/j. enfcli.2018.11.013

PMid:30745163

58. Bhanu V, Shobha C, Narahari M, Kurian J, Lalremruata B, Laldinpuii $\mathrm{E}$, et al. Study of impact of health education on knowledge, attitude and practice related to dengue fever. World J Pharm Pharm Sci. 2015;4210(10):748-61.

59. Usman H, AISahafi A, Abdulrashid O, Mandoura N, Al Sharif K, Ibrahim $A$, et al. Effect of health education on dengue fever: A comparison of knowledge, attitude, and practices in public and private high school children of Jeddah. Cureus. 2019;10(12):e3809. https://doi.org/10.7759/cureus.3809 PMid:30868023

60. Hasanah $\mathrm{N}$, Indriatie. Health education in increasing prevention behavior of dengue hemorrhagic fever in families at Gubeng Village, Surabaya, Indonesia. Indian J Public Heal Res Dev. 2019;10(11):1977. https://doi. org/10.5958/0976-5506.2019.03845.2

61. Harapan H, Ryan M, Yohan B, Abidin RS, Nainu F, Rakib A, et al. Covid-19 and dengue: Double punches for dengue-endemic countries in Asia. Rev Med Virol. 2020;31(2):e2161. https://doi. org/10.1002/rmv.2161

PMid:32946149

62. Masyeni S, Santoso MS, Widyaningsih PD, Asmara DW, Nainu $F$, Harapan $H$, et al. Serological cross-reaction and coinfection of dengue and COVID-19 in Asia: Experience from Indonesia. Int J Infect Dis. 2021;102:152-4. https://doi. org/10.1016/j.jijid.2020.10.043 PMid:33115680

63. Asian Development Bank, World Health Organization. Managing Regional Public Goods for Health: Community-based Dengue Vector Control. $1^{\text {st }}$ ed. Manila: Asian Development Bank, World Health Organization; 2013. p. 3-17. https://doi.org/10.22617/ brf200128-2 